Volume: 06, Issue: 06 "November-December 2020"

\title{
ASSESSMENT OF GROUND WATER CONDITIONS AND RESPONSE PHYSIOLOGY OF MUNG BEAN PLANT DURING STOPPING OF WATER
}

\author{
Wasito $^{1}$, Ahadiyat Yugi Rahayu ${ }^{2}$, Ismangil ${ }^{2}$, Totok Agung Dwi Haryanto ${ }^{2}$ \\ ${ }^{1}$ Academy of Agriculture HKTI Banyumas, Central Java, Indonesia \\ ${ }^{2}$ Faculty of Agriculture, Universitas Jenderal Soedirman, Purwokerto, Central Java, Indonesia \\ DOI: https://doi.org/10.51193/IJAER.2020.6603
}

\begin{abstract}
This study aims to determine soil moisture content when the mung bean plants experience permanent wilting and assessment of the physiological response of the mung bean plants when not given water. The characteristics analyzed were: soil moisture content, plant witheredness, proline content, plant height, and number of leaves. All evaluated characteristics reachedin the early vegetative phase, mung bean plants do not experience wilting; in the early generative phase, the soil moisture content when the mung bean plant withers is $18.20 \%$; if the soil moisture content decreases, are higher the proline level, plant height, and number of leaves.
\end{abstract}

Keywords: soil moisture content, physiological response, mung bean

\section{INTRODUCTION}

Mung beans are one of the agricultural commodities that have good prospects for development in Indonesia. Mung beans are the third most important legume crop after soybeans and peanuts. One of the causes is the increasing demand for consumption and processed industries (Ministry of Agriculture, 2012). Mung beans are a secondary crop, have advantages over other food crops, namely early age (55-65 days), water requirements for growth are $700-900 \mathrm{~mm} /$ year, can be planted on less fertile land, and can be used as soil fertilizers.

According to Sumarji (2013), the productivity of mung beans at the farmer level is only 0.7 tons/ ha, whereas at the research level, the productivity is 2 tons/ ha. The factors that cause low productivity of mung beans at the farmer level are: (1) lack of availability of superior varieties, (2) suboptimal farming techniques, (3) disturbance of plant pests (OPT), (4) socio-economic constraints, (5) climate change, and (6) excess or lack of water (water stress). 
International Journal of Agriculture and Environmental Research

ISSN: 2455-6939

Volume: 06, Issue: 06 "November-December 2020"

Drought induces cell damage (Levitt, 1980). Drought is a term to state that plants experience water shortages due to limited water from the growing medium. Drought in a long time is called drought stress. When $60 \%$ of the water from the root layer has been used, plants will show symptoms of drought (Kuswantoro, et al., 2011). Drought stress results in changes in morphology, physiology, and biochemistry, which adversely affect plant growth and yield. Drought stress in plants can be caused by insufficient water supply in the root zone and excessive water demand by leaves due to evapotranspiration rates that exceed water absorption rates even when sufficient groundwater is available (Levitt, 1980).

The effect of water stress on plant physiology depends on the level of stress experienced and the type or cultivar planted. The initial effect of plants that are stressed by lack of water is the occurrence of obstacles to the opening of leaf stomata which then has a major effect on physiological and metabolic processes in plants. The results of Sianipar et al. (2013) study stated that the highest number of mung bean pods per plant was found in the $100 \%$ drought stress treatment, the field capacity was 2.03 pods, while the lowest was found in $40 \%$ of the field capacity of 1.57 pods. The results of Lapanjang et al. (2008) research show that the weight of dry plants (stems, leaves, roots) decreases with increasing drought stress. Furthermore, Lapanjanget al.(2008), at groundwater content of $60 \%$ field capacity (KL) dry stem weight, dry leaves, dry shoots, and dry plants (total) respectively $33.99 ; 23.19 ; 28.0$ and $27.08 \%$, while the soil moisture content was $40 \%$ field capacity, dry stem weight, dry leaves, dry shoots, and dry plants (total) 74.96 respectively; $76.56 ; 75.85$; and $74.87 \%$.

According the adverse effects of drought, it is necessary to study the critical period of mung beans plants and its impact on physiological responses to obtain drought tolerant varieties. The aim of this research was to determine the water content of the soil when the mung bean plants experienced permanent wilting, and to study the physiological responses of the plants during the absence of water.

\section{MATERIAL AND METHODS}

The experiment was conducted on greenhouse at Sidabowa village, sub-district of Patikraja, district of Banyumas, Central Java, Indonesia ( $7^{\circ} 45^{\prime} \mathrm{S}, 109^{\circ} 21^{\prime} \mathrm{W} ; 75 \mathrm{~m}$ a.s.1). The experiment was carried out by planting mung beans in a pot containing $18.75 \mathrm{~kg}$ of soil (oven dry equivalent). This study used a non-factorial randomized complete block design (RAKL).The treatments tested were potting soil without plants (T0) and potting soil with plants (T1).

Six pots of soil without plants and 6 pots of soil with plants for the early vegatative phase of observation, six pots of soil without plants and 6 pots of soil with plants for observation of the 
early generative phase, and 6 pots of soil without plants and 6 pots of soil with plants for observation of the filling seeds phase.

The observation pots of early vegetative phase, early generative phase and filling seeds phase are maintained at field capacity. In observation of early vegatative phase, after 6 days of age, the water supply was stopped until the age of 16 days. In the observation of early generative phase, after 26 days of age, water supply was stopped until the age of 35 days. In the observation of the filling seeds phase, after 46 days of age, the water supply was stopped until the age of 55 days.

The variables observed in each phase were soil moisture content, plant witheredness, proline content, plant height, and number of leaves. Observation data were analyzed by regression analysis.

\section{RESULTS AND DISCUSSION}

Soil moisture content and plant witheredness of mung bean at each phase are shown in Table 1.

Table 1: Soil moisture content and plant witherednessof mung bean

\begin{tabular}{ccccccc}
\hline & \multicolumn{2}{c}{$\begin{array}{c}\text { Early vegetative phase } \\
\text { Soil } \\
\begin{array}{c}\text { Day of } \\
\text { observation } \\
\text { moisture } \\
\text { content } \\
(\%)\end{array}\end{array} \quad \begin{array}{c}\text { Plant } \\
\text { witheredness }\end{array}$} & $\begin{array}{c}\text { Eorly generative phase } \\
\text { moisture } \\
\text { content }(\%)\end{array}$ & $\begin{array}{c}\text { Filling seed phase } \\
\text { Plant } \\
\text { witheredness }\end{array}$ & $\begin{array}{c}\text { Soil } \\
\text { moisture } \\
\text { content } \\
(\%)\end{array}$ & $\begin{array}{c}\text { Plant } \\
\text { witheredness }\end{array}$ \\
\hline 1 & 44.96 & F & 27.90 & F & 16.54 & PW \\
2 & 44.19 & F & 27.28 & F & 14.09 & PW \\
3 & 43.60 & F & 25.13 & F & 13.83 & PW \\
4 & 42.55 & F & 24.10 & F & 13.61 & PW \\
5 & 41.99 & F & 23.27 & F & 13.29 & PW \\
6 & 40.95 & F & 22.02 & F & 13.09 & PW \\
7 & 40.02 & F & 21.48 & F & 10.88 & PW \\
8 & 39.22 & F & 20.49 & F & 10.58 & PW \\
9 & 38.54 & F & 19.43 & F & 10.24 & PW \\
10 & 37.36 & F & 18.20 & PW & 10.03 & PW \\
\hline
\end{tabular}

F: Fresh; PW: Permanent Wilt

Based on Table 1, mung bean does not experience wilting in the early vegetative phase. the soil moisture content is still sufficient for plant growth in early vegetative phase. In early generative phase, the soil moisture content when the mung bean plant withers is $18.20 \%$. The decrease in soil moisture content is caused by water evaporation in the soil and plants, resulting in drought 
stress. This is in line with Prihastanti (2010) which states that one of the causes of drought stress is high evaporation which exceeds the supply of groundwater to the roots. The soil moisture content of $18.20 \%$ is not sufficient for plant growth.

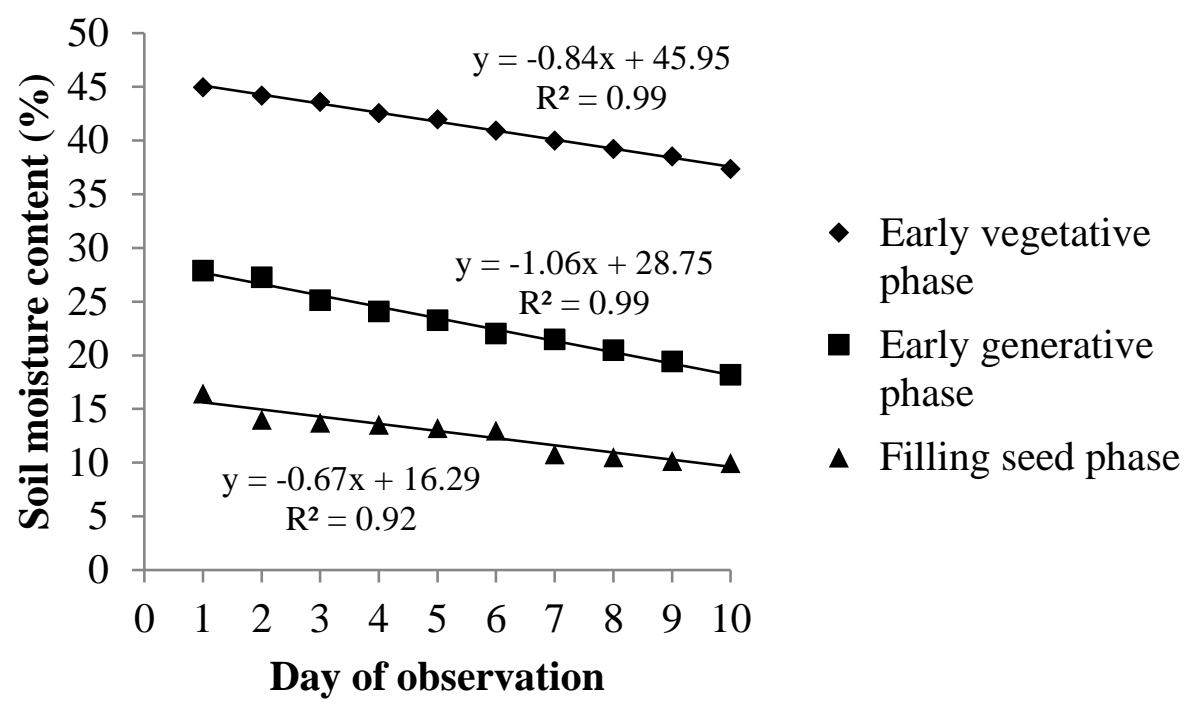

Figure 1: Soil moisture content at each growth phase of mung bean

Figure 1 shows a decrease in soil moisture content at each growth phase. This decreasing soil moisture content indicates that as long as water supply is stopped, the weight of groundwater decreases. Reduction in groundwater weight is caused by evaporation of water through the soil surface and plants. According to Jaleel et al. (2009) the availability of ground water decreases and atmospheric conditions cause continuous water loss through transpiration or evaporation.

The decrease in soil moisture content in the initial generative phase is due to the extraction of groundwater by roots due to plant demand, while the availability of groundwater does not increase (Sowmen, 2013). In the early generative phase, the rate of reduction in soil moisture content is faster than the early vegetative phase because the plants are getting bigger, so they need more water.

Stopping water supply during the filling seed phase, mung bean plants have reached a permanent wilt point. This permanent wilting point indicates that the soil moisture content is not sufficient for the growth of mung bean plants. This is because on days 46 to 55 the groundwater content is $16.54 \%$ and continues to decline to $10.03 \%$. The soil moisture content at the point of permanent wilting is $24.01 \%$, the soil moisture content on days 46 to 55 is below the point of permanent wilt. This fact shows that the roots of mung beans plants cannot absorb water, and this is the plant that has experienced drought stress. Plant roots cannot absorb groundwater because the 
attractive force between water and soil is greater than the attractive force between roots and water (Rusyani, 2014). In addition, due to lack of water supply in the root area (excessive water demand by leaves) due to the rate of evapotranspiration (Song et al., 2011).

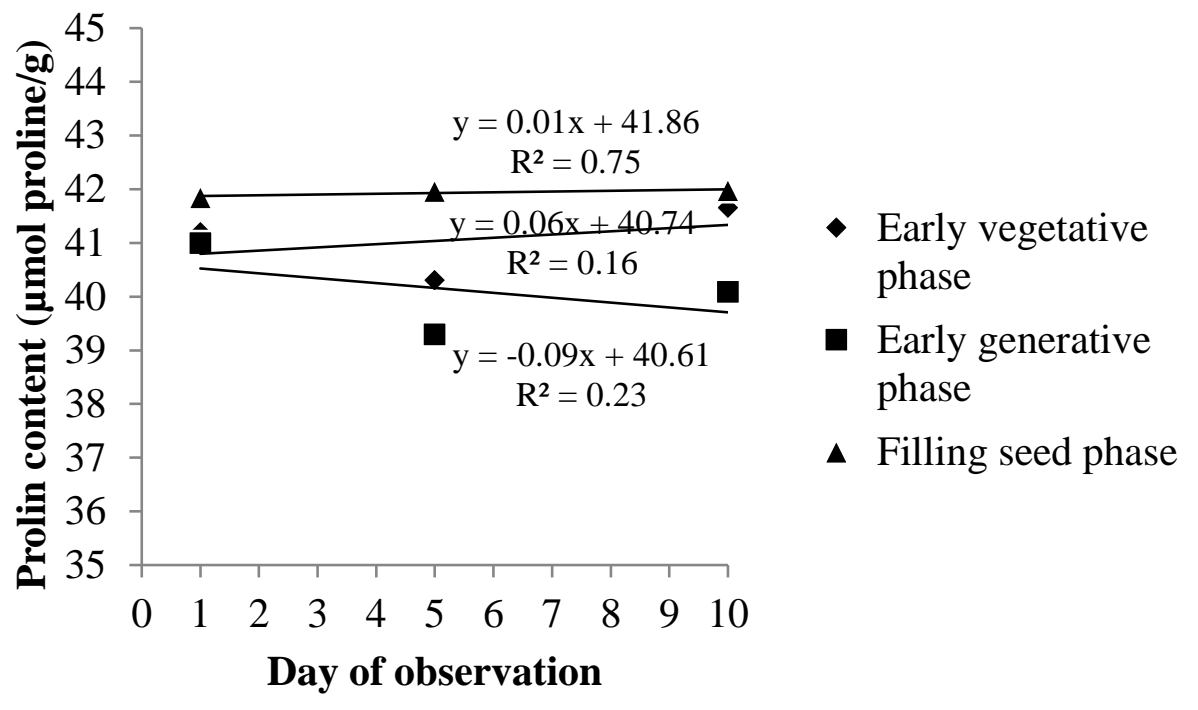

\section{Figure 2: Proline content at each growth phase of mung bean}

There was an increase in proline levels because the soil moisture content decreased (Figure 2). In conditions of water shortage, plants respond to cell osmotic adjustment by producing proline compounds (Hidayat, 2005). In drought-stressed conditions glutamic acid is a precursor to proline formation via the glutamic acid pathway. Glutamate kinase phosphorylase and pyrroline5-carboxylate synthetase (P5CS) catalyze the conversion of glutamic acid to glutamyl phosphatase which is then further reduced to glutamate semialdehyde (GSA) by the action of the enzymes glutamyl phosphate reductase and P5CS. Furthermore, through the cyclation process that occurs spontaneously, there is a change in glutamate semialdehyde to pyrroline-5carboxylate (P5C). Pyrroline-5-carboxylate reductase (P5CR) enzymes convert P5C to proline. Ronde et al. (2000) stated that the decrease in groundwater content can cause plants to induce proline to maintain cell turgor pressure. This is also supported by the statement of Heldt (2005), that proline functions as a protective substance against leaf damage when dehydration occurs.

Table 2 shows the effect of soil water content on plant height and number of leaves. Plant height and number of leaves continued to increase despite a decrease in soil moisture content. The increase in plant height ang number of leaves in the early vegetative phase is due to efficient absorption of nutrients and water, as well as light, which indicates that more photosynthate is obtained for growth, thus extending and adding to the internodes in plants. Gardner et al. (1991) stated that the vegetative growth stage, drought stress can inhibit plant height, leaf formation, 
and increase in leaf area. According to Zulfita (2012) that in the vegetative growth stage, water is used by plants for cell division and enlargement which is manifested in plant height increase and leaf propagation.

Table 2: Plant height and number of leaves of mung bean

\begin{tabular}{ccccccc}
\hline $\begin{array}{c}\text { Day of } \\
\text { observation }\end{array}$ & $\begin{array}{c}\text { Early vegetative phase } \\
\text { Plant } \\
\text { height } \\
(\mathrm{cm})\end{array}$ & $\begin{array}{c}\text { Eumber } \\
\text { of leaves } \\
(\text { sheet })\end{array}$ & $\begin{array}{c}\text { Early generative phase } \\
\text { Plant } \\
\text { height } \\
(\mathrm{cm})\end{array}$ & $\begin{array}{c}\text { Fumber } \\
\text { of leaves } \\
\text { (sheet) }\end{array}$ & $\begin{array}{c}\text { Filling seed phase } \\
\text { Plant } \\
\text { height } \\
(\mathrm{cm})\end{array}$ & $\begin{array}{c}\text { Number of } \\
\text { leaves } \\
\text { (sheet })\end{array}$ \\
\hline 1 & 6.10 & 3 & 26.20 & 13 & 50.20 & 21 \\
2 & 6.40 & 3 & 27.00 & 14 & 50.20 & 21 \\
3 & 7.00 & 4 & 27.60 & 15 & 50.20 & 21 \\
4 & 7.40 & 4 & 28.10 & 18 & 50.20 & 21 \\
5 & 7.80 & 5 & 29.00 & 20 & 50.20 & 21 \\
6 & 8.40 & 5 & 29.50 & 21 & 50.20 & 21 \\
7 & 9.00 & 6 & 30.20 & 22 & 50.20 & 21 \\
8 & 10.00 & 6 & 31.00 & 23 & 50.20 & 21 \\
9 & 11.00 & 7 & 32.50 & 24 & 50.20 & 21 \\
10 & 11.40 & 7 & 33.00 & 25 & 50.20 & 21 \\
\hline
\end{tabular}

Addition of plant height and number of leaves still occurs until the early generation phase. This means that at the stage of plant development, stopping water supply does not affect the uptake of certain nutrients. Tambunan (2009) states that plants need sufficient nutrients for the photosynthesis process to produce photosynthate and assimilates which plants will use for vegetative growth.

\section{CONCLUSION}

All evaluated characteristics reached in the early vegetative phase, mung bean plants do not experience wilting; in the early generative phase, the soil moisture content when the mung bean plant withers is $18.20 \%$; if the soil moisture content decreases, are higher the proline level, plant height, and number of leaves.

\section{REFERENCES}

Gardner, F.P., E.B. Pearce., \& R.L. Mitchell. 1991. Cultivated Plant Physiology. Jakarta UIPress. Translation: HerawatiSusilo. 
International Journal of Agriculture and Environmental Research

ISSN: 2455-6939

Volume: 06, Issue: 06 "November-December 2020"

Heldt, H.W., 2005, Plant Biochemistry, 3rd Edition, 263, Elsevier Publisher, Philadelphia.

Hidayat, P. 2005. Adjustment of Osmosis as Indicator of Drought Tolerant Selection in Soybean. Dissertation. Padjadjaran University Graduate Program, Bandung.

Jaleel, C.A, Manivannan P, Wahid A, Farooq M, Somasundaram R, Panneerselvam R. 2009. Drought Stress In Plants: A Review On Morphological Characteristics And Pigments Composition. Int J Agric Biol. 11: 100-105.

Ministry of Agriculture. 2012. Food Consumption Statistics 2012. http: // pusdatin. General Secretary. agriculture. go. id / tinymcpuk / images / files / Statistik_Kentuk_2012.pdf accessed on January 16, 2017.

Kuswantoro, H., Suhartina. 2011. Soybean Plant Breeding Tolerant to Drought Stress. Palawija Bulletin No. 21. Bogor.

Lapanjang, I., B. S. Purwoko, Hariyadi, S. W. Budi Melati. R, M. 2008. Evaluation of Several Jatrophacurcas (Jatrophacurcas L.) Ecotypes For Drought Stress Tolerance. J. Agron. Indonesia 36: 263-269.

Levitt, J. 1980. Responses of Plant to Environmental Stresses. II Water, Radiation, Salt And Other Stresses. 2nd Ed. Academic Press. New York.

Prihastanti, E. 2010. Chlorophyll Content And Growth Of Cacao Seedlings (Theobroma cacao L.) In Different Treatments Of Drought Stress. Journal.Biome Vol. 12, No. 2.Undip. Semarang.

Ronde, J.A., Mescth, V.D., Steyn, H.F.S. 2000.Proline Accumulation in Response to drought and heat sterr in cotton. African Crop Science Journal, 8 (1): 85-91.

Rusyani, Rini. 2014. Potential of Genjer Plants as Phytoremediation Agents in Waste Containing Lead Metal (Pb). Description.Gorontalo: Gorontalo State University.

Sianipar J., Agustina L. P. P., Syafruddin, I. 2013, Effect of Gamma Ray Radiation on Mung Bean (Vignaradiata L.) Plants in Drought Conditions. Online Journal of Agroecotechnology Vol. 1, No. 2, March 2013.

Song, Nio and Banyo, Yunia. 2011. Leaf Chlorophyll Concentration as an Indicator of Water Deficiency in Plants. Journal of Scientific Science Vol. 11 No. 2. Pg. 169-170.

Sowmen, S. 2013. Adaptation of Forage Legumes Against Drought and Mycorrhizal Inoculation. Thesis, Bogor Agricultural Institute. Bogor. 
Sumarji. 2013. Report on the Extension of Mung beans (Vignaradiata (L) Wilczek) Cultivation Techniques. Islamic University of Kediri. Kediri.

Tambunan, E. R. 2009. Growth Response of Cocoa (Theobroma cacao L.) Seeds on Subsoil Growing Media Using Agricultural Waste Compost and Inorganic Fertilizer. USU's Faculty of Agriculture Thesis. Field.

Zulfita, D. 2012. Physiological Study of Aloe Vera Plants by Cutting the Fronds in Drought Stress Conditions. J. Plantation \& Tropical Land. 2 (1): 1-8. 